\title{
Oil prices and the South African economy: A macro-meso-micro analysis
}

\author{
Ismaél Fofana $^{a}$, Margaret Chitiga ${ }^{b}$ and Ramos Mabugu ${ }^{c}$ \\ ${ }^{a}$ Laval University, Québec, Canada \\ ${ }^{\mathrm{b}}$ Department of Economics, University of Pretoria, South Africa
}

${ }^{c}$ Financial and Fiscal Commission, 73 Verbenia Street, Lynnwood Ridge, 0081 Pretoria, South Africa

\begin{abstract}
Three levels of analysis are used to track the channels by which South Africa and its people are impacted by an increase of oil prices, namely the macro-economic level, the meso-economic level and the micro-economic/household level. The paper uses an economy and energy integrated approach to quantify these different channels. The approach combines a household survey dataset and an input-output dataset to implement the models. Results indicate that the impacts on the macroeconomy are negative, with gross domestic product falling and the current account balance worsening. All of the industries falling into the high intensive oil - use group witness an increase of their input cost that is above the economy - wide average. The impact of doubling paraffin prices results in poor households in rural areas and among the "Black" population, in particular, witnessing an increase of their cost of living which is much higher than their corresponding highest expenditure quintile groups. An increase of transport fuel hits the richer households much harder. The distributional impacts of rising transport cost as a consequence of high oil and oil-products prices shows that median quintile expenditure groups observe the highest impact both in urban and rural areas and especially among the "Black" population.
\end{abstract}

Keywords: Oil; Welfare; South Africa

JEL classification codes: $\mathrm{H} 2 ; \mathrm{D} 57$; R2 


\section{Introduction}

The rapid and large increase in the oil price experienced over the last years has created widespread concern about its impacts on economic growth and poverty in many developing countries. Fig. 1 shows that oil is now more expensive in real terms than at any other time since 1980. The impact of this rapid increase has been estimated to have negative effects on the gross domestic product (GDP) of oil-importing countries as well as overall world GDP. The adverse impact of higher-oil prices is much more diversified among oil-importing countries depending on the share of oil cost in national income and the energy efficiency and substitution possibilities of the economy. An increase of oil prices also impacts differently on industrial sectors, and on individuals within a country. South Africa falls within the group of oil-importing countries and thus is likely to see reduced per-capita GDP as a result of continued and rapid oil price increases. ${ }^{1}$ Different sectors and households are likely to be impacted differently depending on their dependence on oil and oil products.

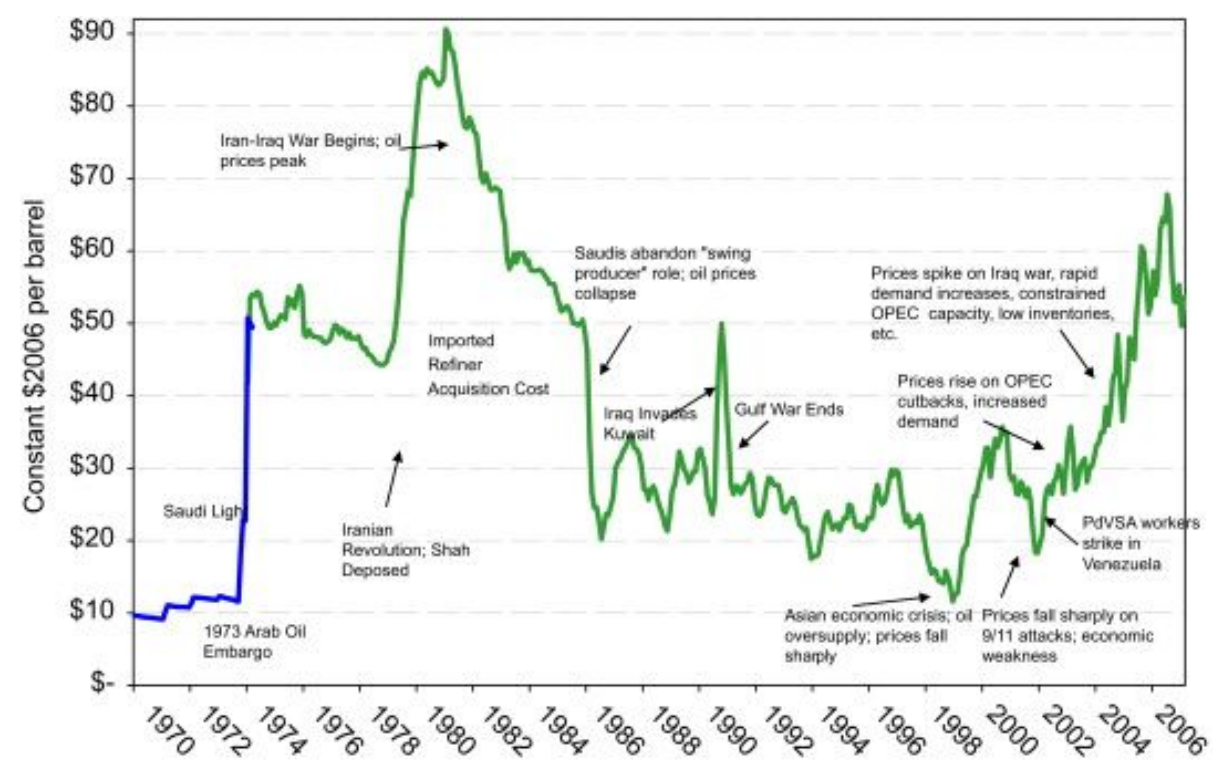

Fig. 1. Annual Average Crude Oil Prices (US Dollar per barrel),

Source: http://www.beodom.com/assets/images/blog/peakoil/crude-oil-prices-1861-2008.jpg.

This paper evaluates the structural and distributional impacts of higher-oil prices on the South Africa economy. It uses energy focused economy-wide methodologies designed to capture both 
direct and indirect effects of the oil shock. The study combines a household survey dataset and an input-output (IO) dataset to implement the models. Previous studies that have addressed a similar issue in South Africa are McDonald and van Schoor (2005) and Essama-Nssah et al. (2007). They use a computable general equilibrium (CGE) macro-micro framework to understand the structural and distributional consequences of oil price increases. ${ }^{2}$ While this paper builds on these studies, it is unique because it uses IO data combined with household survey data analysis which allows a highly disaggregated analysis.

The rest of the paper is arranged in five sections. Section 2 presents the methodological approaches and data used in the economic impact assessments of this study while Section 3 sheds light on the hypothesis about the economic and social impacts of high oil price in South Africa. Section 4 concludes the paper.

\section{Methodology and data}

Different approaches have been used in assessing the economic impacts of high oil and oilproducts prices. These methods are here clustered into two main groups, namely the macro- and micro-economic approaches. The macro-economic models assess the impact of oil price changes on macro-economic variables such as the GDP, exchange rate, inflation and employment (e.g. the Organisation of Economic Cooperation and Development (OECD)'s Interlink model, (see Richardson, 1988), The International Monetary Fund (IMF)'s Multimod model, (see Faruqee et al., 1998) and the International Energy Agency (IEA)'s World Energy Model, (see IEA, 2009)). This group also includes the general equilibrium frameworks which simulate the working of the economy by taking into account the structure of the economy and interactions between sectors and agents, as well as the direct and indirect effects of external shocks and macro-economic policies (e.g. GEM-E3 model ${ }^{3}$; REGEMI ${ }^{4}$; African Development Bank Structural Model; etc.). The principal failure of macro techniques is that they do not quantify the distributional and welfare effects among the population as does the micro-economic assessment.

The micro-economic approach uses household surveys for estimating the direct and indirect effects of oil shocks on the cost of living and the well-being of households. Higher prices of oil and oil products increase the cost of living through direct and indirect effects. The direct effects of oil price rises pass onto petroleum-products (notably gasoline, liquefied petroleum gas (LPG), and kerosene) purchased directly by households. The indirect effects of oil-product price 
increases are much more complex and pass through the input cost of products consumed by households. For example, the increase of diesel cost contributes to the increase of transport costs and then to the increase of food costs. The extent to which such effects affect the various groups of households depend on the relative share of oil and oil products, and the oil-input intensive products in household budgets. Besides accounting for the direct effects, the calculation of the full price impacts should integrate the chain of indirect effects as well as the share of each product in the total household budget. This requires the availability of both an input and output table and a household expenditure survey.

A number of studies have assessed the impact of important energy price increases using a household expenditure survey, and sometimes an IO table. The IMF has recently reviewed studies which estimate the direct effects of price increases through the share of petroleumproducts prices in the budget, or both direct and indirect price increases of goods whose prices have been affected by the shock, (IMF, 2000). However, most of these studies assume that households' behaviour remains unchanged before and after the shock. This is certainly not likely to be true. In order to make an appropriate analysis on households, one needs to consider the ability of households to switch away from oil products and to switch to other products depending on their relative prices. The availability of own and cross elasticities allows us to make some adjustments to household purchases for the different prices and provide a better estimation of the cost of living standards.

In order to understand the magnitude and distributional effects of an oil price shock and consequently to help in formulating policies to ameliorate these effects, three levels of analysis are used to track the channels by which South Africa and its people are impacted by an increase of oil prices:

- The macro-economic level, looking at the impacts of oil shocks on the total national economy, that is, the current account balance, inflation, budget deficit, GDP and unemployment.

- The meso-economic level, related to the distributional impacts of higher-oil prices among industries and its translation into the prices of factors and commodities.

- The micro-economic level, which looks at the distributional impacts on households' real income and welfare.

\subsection{The macro-economic impacts}

Following the study of the United Nations Development Program/World Bank Energy Sector Management Assistance Programme (UNDP/ESMAP) (2005), the analysis uses a simple net 
import formulation to quantify the direct effect of oil price increases on GDP. ${ }^{5}$ This is reflected in the following simple linear equation linking the percentage change in GDP to the percentage change of the price of imported oil, the ratio of net imports of oil to GDP, and the price elasticity of energy demand:

$\triangle G D P=\Delta p m(1-\varepsilon) \frac{N M}{G D P}$

where $\triangle G D P$ is the percentage change in GDP, $\triangle p m$ the percentage change in the price of imported oil, $\varepsilon$ the absolute value of the price elasticity of oil demand, and $N M$ the net imports of oil. The approach assumes that the entire adjustment of a terms-of-trade deterioration following a large and sustained oil price increase will be reflected by a reduction in GDP. This hypothesis holds when a particular country does not have excess reserves to spend, and is not able to raise additional external financing. However, the formulation accounts for non-zero price elasticity as the economy gradually adjusts and mitigates the severity of the initial shock. Thus, the more elastic is oil demand, the less a price increase reduces GDP. The price elasticity of oil demand for South Africa has been fixed at an average of -0.2 following a recent study conducted by Smit et al. (2003).

\subsection{The meso-economic impacts}

High oil and oil-products prices modify the entire price structure and, consequently, commodity prices and factor returns in oil-importing countries such as South Africa. The differential impacts on activity production depend primarily on their oil and oil products input intensity which can be measured as oil and oil products input cost per unit of the product. An industry with a high oil and oil products intensity is more likely to be affected negatively by higher-oil prices than one with lower intensities. Different industries within an economy have also different capabilities for inter-fuel substitution. The inter-fuel substitution possibility reduces the vulnerability of the industry to an oil shock. The industry's energy input combination could be a good measure of its ability to substitute oil for other energy sources according to its relative cost. Sectoral structure and rigidities also determine the short and long run adjustment process. When quantity (inputs, factors, and outputs) adjustments are high, higher-oil prices would be translated into smaller reductions in factors and output prices with an efficient allocation of resources across industries. 
The meso-economic impacts of high oil prices are captured through changes in the products' cost. One has to consider the analysis as a first order (or direct) impact assessment. In turn, changes in the product cost affects the (consumers and producers) demand for the product, and then impacts on the quantity produced, and the demand for input and productive factors, and the factor prices, and so on. To fully account for the direct and the complex chain of indirect effects, one should use an appropriate framework that accounts for interactions among sectors and economic agents. ${ }^{6}$ The estimation of the distributional effects of high oil prices among sectors uses data provided by the Supply and Use Tables to set up the average cost structure of products. The change in the input or consumption cost $\Delta C_{i}$ by institutional sector $i$ (government, corporations or households) as a result of the increase of oil and oil-products prices can be formulated as follow:

$\Delta C_{i}=\left(\sum_{p} c_{p, i}^{1}-\sum_{p} c_{p, i}^{0}\right) / \sum_{p} c_{p, i}^{0}$

$c_{p, i}{ }^{0}$ and $c_{p, i}{ }^{1}$ are the user cost of product $p$ by consumer $i$ before and after the oil shock took

place. For oil and oil products $(o p) c_{o p, i}{ }^{1}=2 c_{o p, i}{ }^{0}$, and for non oil products $(n p) c_{n p, i}{ }^{1}=c_{n p, i}{ }^{0}$, with $\{o p, n p\} \in p$. The value of $c_{p, i}{ }^{0}$ is given by the Supply and Use Tables.

\subsection{The micro-economic impacts}

Higher-oil prices lead to a global loss of welfare as a consequence of adverse income and price effects. The reduction in aggregate demand induced by the oil price rise leads to a loss of output and employment and a reduction of factor prices. In addition, households face an increase in their consumption prices. As a result, the cost of purchasing the same bundle of goods increases after the oil price rise. The distributional impacts within society depend on the factor endowments and on the consumption patterns of different groups, as well as their ability to substitute one product for another. In order to estimate the full impacts of the oil price rise on households and individuals, one needs to consider together the income effects (including the effects on government revenues and spending) and the cost of living or consumption effects. Higher-oil prices reduce domestic demand (both consumption and investment) which in turn reduces imports and domestic production. If real wages are sticky downwards this is translated into an increase of unemployment in the economy. In addition, higher input costs and lower demand reduce business profits and, therefore, capital returns. Households and individuals are 
affected differently depending on their factor (capital and labour) endowments. The sectoral distribution and the characteristics of the labour (e.g. skill categories) and capital factors are also crucial in the distribution of income among individuals and households.

Higher prices of oil and oil products increase the cost of living through direct and indirect effects. The direct effects of oil price rises pass onto some petroleum-products (notably petrol, diesel, kerosene, LPG, etc.) purchased directly by households. The magnitude to which such effects affect the various groups of households depends on the relative share of petroleumproducts in household budgets. A household expenditure survey can be used to measure the direct effects of oil price shocks on households. However, these results can be misleading if analysts fail to account for the indirect effects, particularly in the case of a large shock, such as those currently occurring. The estimation of the indirect effects of oil-product price increases is much more complex than the direct effects and requires an IO table.

We measure the impacts of changes in oil prices in South Africa by estimating its direct and indirect effects on the cost of living for different household groups. The direct effects are measured through the petroleum-products purchased by households and require an estimation of their shares in household expenditure for various household categories. The analysis also establishes the impacts of high transport prices as a consequence of an increase of high oil and oil-products prices. We limit our analysis on transport service as it is the most directly impacted sector/product by an oil price rise among products purchased by households.

The analysis uses the Income and Expenditure Survey (IES) for South Africa for the year 2000 which provides detailed information on the cost of household goods and services by purpose or category of expenditure (e.g. housing, food and beverage, fuel, furniture and equipment, health, education, recreation, sport and entertainment, etc.) (Statistics South Africa, 2002). We first isolate households' expenditure on various sources of energy (electricity, gas, firewood, charcoal, paraffin, candles, coal, methylated, petrol, diesel, cells, dung, crop waste, and transport fuel). Households' consumption expenditures are separated from other expenditures (durable assets, transfers, inputs, etc.), and summed into total consumption expenditures. Other household characteristics (residential areas, race, quintile expenditure group, etc.) are also collected. While there has been substantial inflation in South Africa between 1995 and 2000, the 2000 household survey data shows that nominal household per-capita incomes have decreased since 1995, the year of the previous household survey. The same does not apply to household 
expenditure levels, but a closer look at expenditure data shows that the within-household subtotals of various expenditure categories do not add up to household overall totals. In the mean time, Statistics South Africa has changed the unweighted sample composition since 1995, perhaps to reflect the true population of the country. The 2000 sample contains a much larger black population share and a much smaller white population share. This may have generated the above apparent anomalies. Therefore, we use the shares of various population groups from the 2001 census to correct for the latter inconsistency. This adjustment ${ }^{7}$ has been integrated in a consistent manner so that we replicate the country poverty and inequality figures for the year 2000. Then, the resulting data are used for the micro-economic analysis.

\section{The economic impact of high oil prices in South Africa}

The results of implementing the methodologies discussed above are reported in this section. The discussion begins by focusing on specific characteristics of the South African economy. Then a discussion of the impacts at the macro-economic level is given, followed by a discussion of the impacts at the meso-economic level and finally the impacts at the micro-economic level are discussed.

\subsection{The South African economy}

The economic performance of post apartheid South Africa has been relatively impressive, averaging 3.3\% for the real GDP growth rate and $1.4 \%$ in per-capita terms for the period $1995-$ 2005. This growth trend was an improvement, if one compares with the rates of the 1985-1994 period, where the respective average rates were $0.8 \%$ and $-1.3 \%$ (South African Reserve Bank database, various years, (www.reservebank.co.za)).

Final consumption by household and by government far outstripped the contributions made by the other components of GDP. It contributed 67\% while net export and investment represented $20 \%$ and $13 \%$ of GDP in 2000 , respectively. After a long period of increases, the unemployment rate has been declining over the last years. Inflation recorded successively a period of increase and decrease and has been on the increase since 2004. The tertiary sector, with an average growth rate of $3.8 \%$, substantially outperformed the primary and secondary sectors (du Plessis and Smit, 2006). At the other end of the spectrum, the primary sector contributed the least to overall growth with an average real growth rate of only $0.4 \%$. In 2000 , the service sector (private and public) was the most important contributor to GDP, contributing $62 \%$. The manufacturing 
sector represented a relatively important share of $29 \%$ of GDP, while the primary sector (agriculture and mining) contributed less than 10\%.

In terms of contribution to GDP, the 2000 Energy-SAM shows that "General Government" is by far the biggest contributor with $15.0 \%$, followed by "trade services" with $10.3 \%$. "petroleum industry" (including "crude fuel") contributed 3.3\% to GDP and ranked among the top eight contributors out of the 95 industries in the 2000 Energy-SAM.

The current account deficit of the South African economy has been growing sharply since 2003, reaching $12 \%$ of its GDP in 2007. The significant rise of the current account deficit means that the value of imports for goods and services has recorded a more important increase, in particular the import of oil and oil products, than the value of exports.

South Africa has a well-developed synthetic fuels industry facilitated by the country's abundance of coal resources and offshore natural gas. These permit the country to meet $35-40 \%$ of its domestic liquid petroleum requirements while $14 \%$ is exported. Thus, the country presented a high coverage ratio of oil and oil products in the year 2000 compared to a typical net oilimporting country. Petroleum was among the most export oriented industries in 2000.

\subsection{The macro-economic impacts}

We attempt to quantify the economic impacts of a sustained oil price increase above US\$55 a barrel. Our analysis is limited to a 5-year horizon (2001-2006) during which the price of crude oil has more than doubled. ${ }^{8}$ The results reported are for the end of the period. When we assume zero elasticity ${ }^{9}$ for oil and oil products demand we found that a price increase will likely lead to an equivalent increase of the oil import bill as the quantities imported do not change. The oil import bill increases to 20,546 million Rands $(\mathrm{R})^{10}$ which translates to $10.1 \%$ of the total import bill. The increase of oil and oil products values represents a significant shift in the import structure and the trade figures of the country. The value of South African total imports increases by $5.3 \%$. The trade surplus drops by $42 \%$ while the deficit of the balance of payments (BoP) increases to $\mathrm{R}-12,590$ millions from a value of $\mathrm{R}-2,317$ millions. An increase of oil and oilproducts imports is balanced by a decrease of other imports and/or an increase of export products in a budget constrained economy (no excess reserves and no borrowing) thereby putting downward pressure on the exchange rate. As a result, imports become more expensive and exports less valuable and consequently real national income drops. Lower national income 
reduces demand for imported and domestic commodities and investment, leading to a drop of GDP.

Next, the impact of a $100 \%$ increase of oil and oil-products prices on GDP is estimated allowing the economy (producers and consumers) to adjust following the oil shock. This is reflected through the use of an estimate of the oil price elasticity of demand from the literature (Smit et al., 2003). Using the above net import formulation we found that a $100 \%$ increase of oil and oilproducts prices reduces GDP by only $0.2 \%$ in South Africa. The estimated value is lower than the $0.8 \%$ decrease estimated by the World Bank (2005) study for a sustained US $\$ 10$ increase of crude oil prices. The primary reason for the difference between the two estimations is in the assumption on petroleum-products prices. We simulate increases of basic fuel prices ${ }^{11}$ and petroleum-products prices at the same time whereas the World Bank study focuses on the former prices. As South Africa's exports of liquid fuel products represented 14\% of the country's total supply, the ratio of net imports oil to GDP decreases substantially ${ }^{12}$ when one adds petroleumproducts to the simulation.

Higher-oil prices also increase input costs and reduce business profits and lead to a deterioration in consumers' purchasing power. Tax revenues fall and the budget deficit increases because of rigidities in government expenditures. Together higher prices of oil and oil products, upward pressure on the nominal wage and business profits, and government fiscal and monetary management of oil shocks lead to inflation. Wage pressures together with reduced demand induce higher unemployment.

A large and sustained increase of oil and oil-products prices will not significantly impact South African economy. The availability of a large reserve of coal and a well-developed synthetic fuel industry has always been an alternative source of energy cushioning the economy from volatility of international oil prices. Although the oil prices shock tested above shows no major macroeconomic impact, the distributional impacts among sectors and household groups might be important.

The UNDP/ESMAP (2005) study discusses a variety of oil shocks impacts on developing countries, ranging from the impacts on GDP, balance of payments, per-capita income, the degree of self-sufficiency in oil production and oil dependency of energy use. The study indicates that the impact of a sustained US\$10 a barrel price increase will cause a relatively more pronounced negative effect on the GDP of least developed countries (LDCs) than it will have on the GDP of 
developed countries. GDP in most LDCs or poorest countries (with GDP per capital below US\$300) will generally decline by $1.5 \%$. Those countries with larger per-capita GDP saw a loss of $0.5 \%$ of GDP due to the same price shock.

Although ours is not a full CGE study, its results compare well to those of previous CGE studies in South Africa. Similar results were obtained in a computable general equilibrium model by McDonald and van Schoor (2005) using a low elasticity of substitution of consumption for petroleum purchases by households of 0.8 . In that case GDP fell by $1.01 \%$. Similarly, in their CGE model Essama-Nssah et al. (2007) also find a fall in GDP by 1.8\%. In both these papers the mechanisms are the same. There is an increase in the price level and in imports due to the oil price increase shock. The results differ partly because of the sizes of the simulations, the closures selected as well as other assumptions on parameters and their specifications. McDonald and van Schoor (2005) simulated a 20\% increase in the crude oil price while for Essama-Nssah et al. (2007), among other simulations, the world price of imported crude and refined oil is increased by $125 \%$.

\subsection{The meso-economic impacts}

Although the oil prices shock tested above shows no major macro-economic impact, the distributional impacts among sectors and household groups might be important. We measure sectoral oil intensity by the ratio of oil and oil products input cost to the value added. The ratio is

computed for the 94 aggregate industries recorded in the IO table for the year $2000^{13}$ (Table 1). It shows that "primary plastic" is largely the most oil-input intensive industry in South Africa. The industry's oil-input cost per unit of value added is estimated at 0.5 . For simplicity, we focus on the top-ten and the bottom-ten oil-input intensive industries after ranking them from the most to the least oil-input intensity. 
Table 1.

Industry energy profile of South Africa in year 2000 (percent).

\begin{tabular}{|c|c|c|c|c|c|}
\hline & \multicolumn{3}{|l|}{ Share $^{a}$} & \multirow{2}{*}{$\begin{array}{l}\text { Oil } \\
\text { intensity }\end{array}$} & \multirow{2}{*}{$\begin{array}{l}\text { Share of oil in total } \\
\text { energy }\end{array}$} \\
\hline & $\begin{array}{l}\text { Value } \\
\text { added }\end{array}$ & Oil & $\begin{array}{l}\text { All } \\
\text { energy }\end{array}$ & & \\
\hline $\begin{array}{l}\text { High intensive oil-input } \\
\text { industries }\end{array}$ & 10.9 & 49.5 & 32.0 & 17.0 & 77.0 \\
\hline Primary plastics & 0.4 & 4.8 & 2.6 & 47.0 & 93.0 \\
\hline Paints & 0.1 & 0.8 & 0.5 & 21.2 & 77.7 \\
\hline Transport services & 5.6 & 29.3 & 16.4 & 19.6 & 88.5 \\
\hline Tyres & 0.2 & 0.7 & 0.7 & 15.5 & 49.7 \\
\hline Pumps & 0.1 & 0.3 & 0.2 & 14.3 & 80.5 \\
\hline Fertilizers & 0.2 & 0.7 & 0.5 & 13.7 & 81.8 \\
\hline Non-ferrous metals & 0.9 & 3.3 & 5.5 & 13.5 & 30.0 \\
\hline Gears & 0.0 & 0.1 & 0.1 & 12.4 & 57.6 \\
\hline Basic chemicals & 0.4 & 1.2 & 0.7 & 12.0 & 81.4 \\
\hline Agriculture & 3.0 & 8.3 & 4.8 & 10.3 & 86.2 \\
\hline $\begin{array}{l}\text { Low intensive oil-input } \\
\text { industries }\end{array}$ & 16.9 & 2.1 & 11.3 & 0.5 & 9.0 \\
\hline Sugar & 0.2 & 0.0 & 0.1 & 0.6 & 16.7 \\
\hline Electricity & 2.3 & 0.4 & 9.2 & 0.6 & 2.1 \\
\hline Other paper & 0.2 & 0.0 & 0.0 & 0.5 & 57.1 \\
\hline Containers of paper & 0.3 & 0.0 & 0.1 & 0.5 & 23.4 \\
\hline Insurance & 9.7 & 1.2 & 1.4 & 0.5 & 41.6 \\
\hline Beverages and tobacco & 2.4 & 0.3 & 0.3 & 0.4 & 39.0 \\
\hline Wearing apparel & 0.6 & 0.1 & 0.1 & 0.4 & 33.9 \\
\hline
\end{tabular}




\begin{tabular}{|l|l|l|l|l|l|}
\hline & \multicolumn{2}{|l|}{\begin{tabular}{l} 
Share \\
\cline { 2 - 5 }
\end{tabular}} & $\begin{array}{l}\text { Oil } \\
\text { intensity }\end{array}$ & $\begin{array}{l}\text { Share of oil in total } \\
\text { energy }\end{array}$ \\
\hline & added & Oil & $\begin{array}{l}\text { All } \\
\text { energy }\end{array}$ & & \\
\hline Publishing & 0.7 & 0.1 & 0.1 & 0.3 & 29.6 \\
\hline Wire and cable & 0.2 & 0.0 & 0.0 & 0.1 & 66.7 \\
\hline Other food & 0.3 & 0.0 & 0.0 & 0.1 & 33.3 \\
\hline Other industries & $\mathbf{7 2 . 2}$ & $\mathbf{4 8 . 4}$ & $\mathbf{5 6 . 7}$ & $\mathbf{2 . 5}$ & $\mathbf{4 2 . 4}$ \\
\hline All industries & $\mathbf{1 0 0 . 0}$ & $\mathbf{1 0 0 . 0}$ & $\mathbf{1 0 0 . 0}$ & $\mathbf{3 . 7}$ & $\mathbf{4 9 . 7}$ \\
\hline
\end{tabular}

Source: author's calculation using the South African Final Supply and Use Tables, 2000.

${ }^{a}$ Share is calculated as: share of industry-product $j=$ value for industry-product $j /$ sum of value for all industry-product $j$.

The top-ten group - referred to as high intensive oil-input industries - has an oil-input cost per unit of value added greater than 0.1 , with an average of 0.2 for the entire group (Table 1 ). This group contributes $11 \%$ of the total value added and accounts for half of the total oil-input cost. When we use the share of oil bill in total energy input - considering the principal sources of energy in South Africa (that is, coal, petroleum, and electricity) - as an indicator of inter-fuel substitution possibility, we found that most industries of this group have a very limited ability to substitute other fuels for oil. The average share of oil and oil products input cost in the total energy input cost is $77 \%$. Primary plastics, transport services, and agriculture are the most vulnerable industries to high oil prices as they have the highest shares of oil-input cost in total energy input cost. In contrast, non-ferrous metal, tyres, and gears industries are more amenable to inter-fuel substitution possibilities as their average oil shares in energy are relatively low. The bottom-ten group - or low intensive oil-input industries - presents an oil-input cost lower than 0.01 per unit of value added (Table 1). They contribute $17 \%$ of the country's value added and account for $2 \%$ of the total oil-input cost. The average oil intensity is very low as well as the share of oil in total energy input for this group of industries. 
Assuming zero price elasticity of demand for petroleum-products in the short term, any modification in petroleum-products prices will be translated into an increase in the input cost through the oil-input bill. Transport services and primary plastics are likely to be the most affected industries with $23 \%$ and 19\% increases of their input costs, respectively. All of the industries falling into the high intensive oil-use group witness an increase of their input cost above the economy-wide average (Fig. 2).

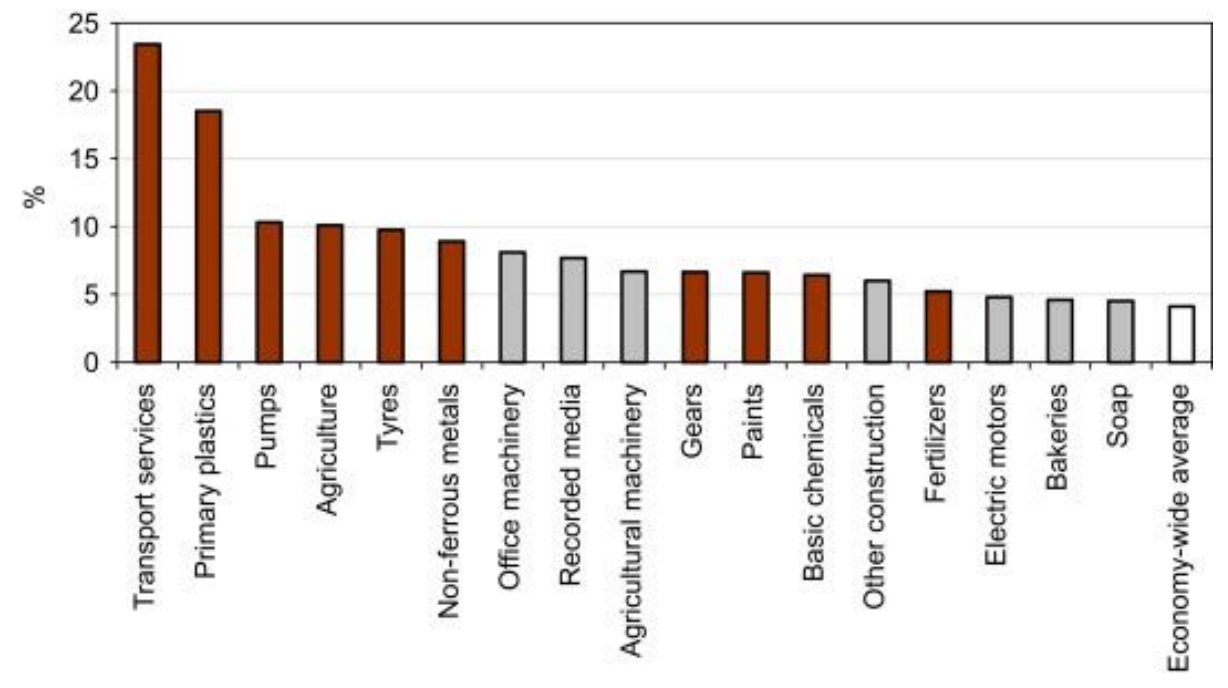

Fig. 2. Percentage change in input cost for selected industries, Source: author's calculation using the South African Final Supply and Use Tables, 2000.

We now assume a low possibility for quantity adjustments in the short term and assess the direct impacts of doubling (100\% increase) the petroleum-products prices on goods and services produced in South Africa. Results are illustrated in Fig. 3 for products/industries which experience an increase of the purchase cost (after taxes) above the economy-wide average. Most of the products/industries observing an important increase of their cost fall into the group of high intensive oil using industries. The incidence is significant on the cost of "transport services" and "primary plastics". As "basic chemicals", "pumps", and "gears" (also high intensive oil-use industries) face high competition with imported goods whose prices have been kept unchanged, they will likely not face a significant increase in their purchaser (average) cost. 


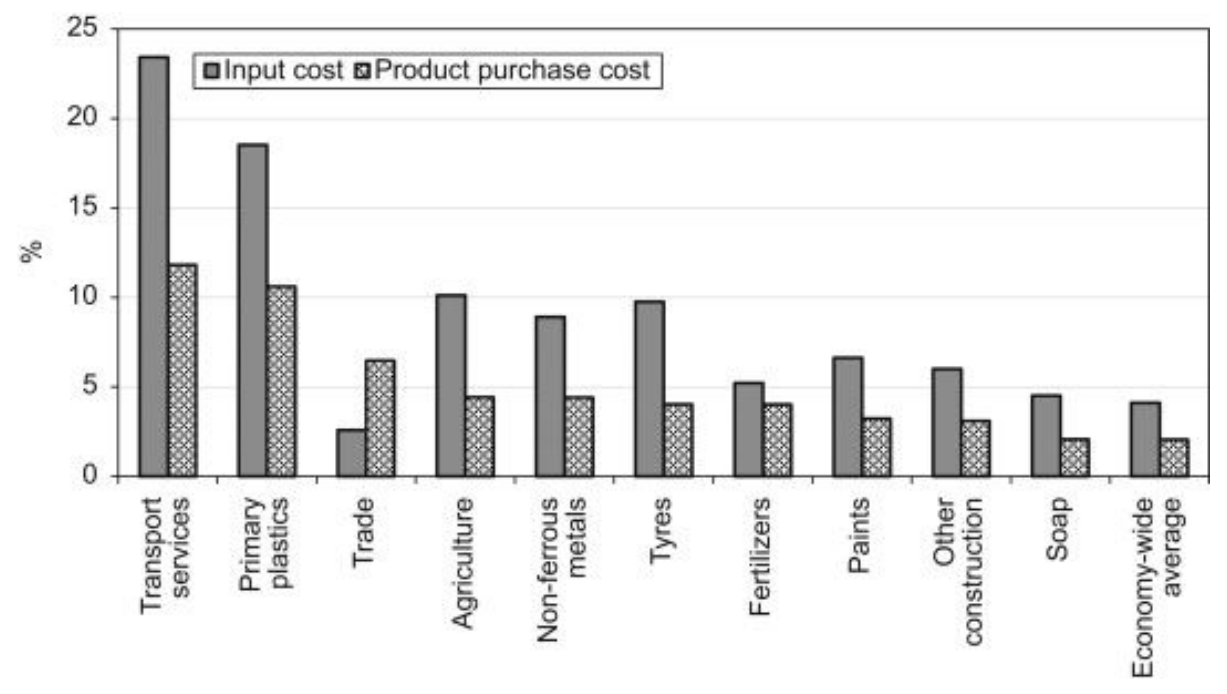

Fig. 3. Percentage change of input and purchase costs for selected industries and products, Source: author's calculation using the South African Final Supply and Use Tables, 2000.

The electricity sector is among the least oil-input intense sectors in South Africa with a share of oil in the total energy input of $2.1 \%$ and an oil intensity of $0.6 \%$ (Table 1 ). It is highly intensive in coal which represents more than $70 \%$ of the sectors' energy input cost. In contrast, transport sector is intensive in oil with an oil intensity of $29.3 \%$ ranking behind the primary plastics and the paints industry (Table 1). With a high share of oil-input cost in energy input cost, large-scale fuel substitution is less likely to occur in the transport sector without substantial financial support from the government. Therefore, high petroleum-products prices are expected to impact more on the cost of transport services and primary plastics as presented in Fig. 3. Comparing the sectoral results to those by McDonald and van Schoor (2005) and Essama-Nssah et al. (2007) shows that the general trend is the same. High oil intensive sectors such as transport services suffer relatively more than the other sectors. The magnitudes differ due to the sizes of the simulations, the chosen closures and other assumptions adopted in the different models.

The impacts of higher-oil prices in the transport and primary plastics industries accounts for the largest share of the effects in other industries. They play a key role in the distributional impacts of high oil prices among industries and households. In the next section, our analysis focuses on the impact of high oil and oil-input products prices on the cost of living. The analysis is limited to the petroleum-products and the transport services as they are the products that seem to play an 
important role in the channel of transmission of oil price shocks. Primary plastic products are not directly consumed by households (Fig. 4).

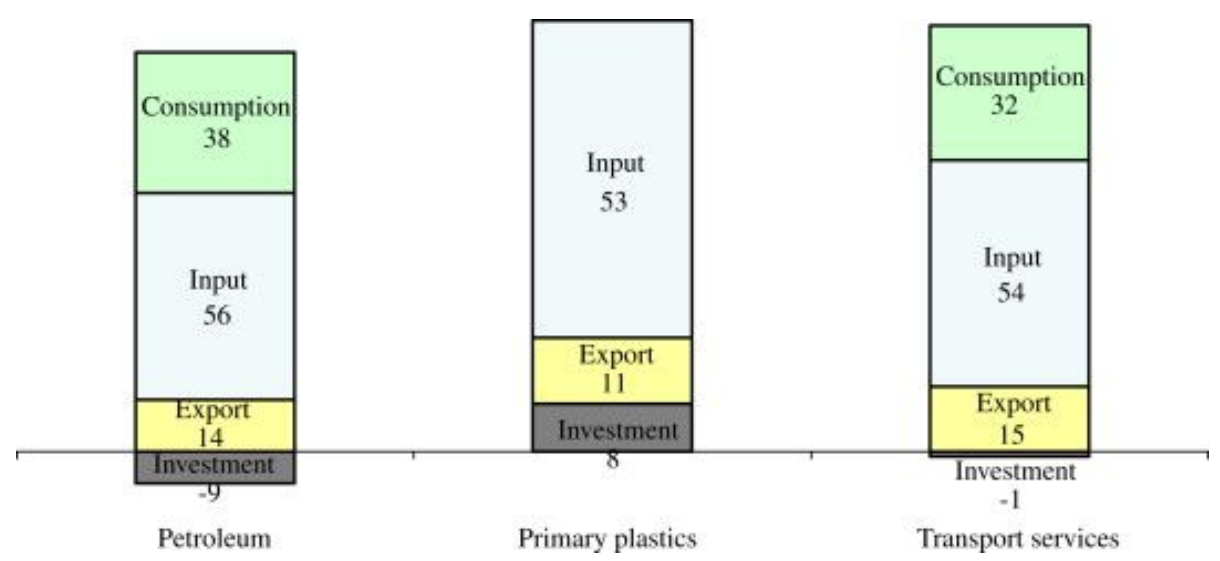

Fig. 4. Structure of the demand for selected products (percent), Source: author's calculation using the South African Final Supply and Use Tables, 2000.

\subsection{The micro-economic impacts}

\subsubsection{Shares of energy and petroleum-products in total household consumption expenditure} Table 2 presents the shares of energy and major petroleum-products in household expenditure for quintile expenditure groups. It shows no significant differences in the shares of energy in total expenditure among quintile groups. In contrast, the share of petroleum-products declines as the total consumption expenditure increases, then increase substantially for the richest quintile. Therefore, petroleum-products as a whole are used most intensively by either high income or low income households. 
Table 2.

Shares of energy and petroleum products expenditure in total household expenditure for quintile in South Africa (percent).

\begin{tabular}{|l|l|l|l|l|l|l|}
\hline & \multirow{2}{*}{ All energy sources } & \multicolumn{5}{l|}{ Petroleum products } \\
\cline { 3 - 8 } & & All & Paraffin & Gas & Other domestic fuel & Transport fuel \\
\hline & & 3.9 & 3.8 & 0.1 & 0.0 & 0.0 \\
\hline Quintile 1 & 8.2 & 3.2 & 2.9 & 0.2 & 0.0 & 0.1 \\
\hline Quintile 2 & 7.9 & 2.6 & 1.9 & 0.2 & 0.0 & 0.5 \\
\hline Quintile 3 & 7.5 & 2.5 & 0.8 & 0.2 & 0.0 & 1.5 \\
\hline Quintile 4 & 7.7 & 4.7 & 0.0 & 0.1 & 0.1 & 4.5 \\
\hline Quintile 5 & 8.8 & 4.2 & 0.5 & 0.1 & 0.1 \\
\hline All & 8.5 & &
\end{tabular}

Source: author's calculation using the South African Income and Expenditure Survey for year 2000.

When distinguishing petroleum-products into domestic products, i.e. paraffin, gas and other fuel (e.g. petrol and diesel) and transport fuel, a significant difference is noted in the expenditure pattern of the lower and the higher quintile expenditure groups. Analysis of the income and expenditure survey for the year 2000 shows that the lowest expenditure groups rely primarily on paraffin as a source of liquid fuel and gas. In contrast, the highest expenditure groups used intensively more transport fuel than the poorest households. This pattern of fuel expenditures shows that significant distributional impacts between rich and poor households will be observed only when there is an important difference in the change in domestic fuel prices compared to transport fuel prices.

The pattern of expenditure among rural and urban household groups is somewhat similar to the entire South African figures with a minor difference that rural households rely more on paraffin compared to urban households (Table 3). ${ }^{14}$ However, in both areas poor households used 
intensively more paraffin and less of other petroleum-products. Rich households, on the other hand, spend more on petrol and diesel for transport, and less on paraffin. The last column of Table 3 shows that transport fuel expenditure in total household expenditure is higher in urban than rural areas. The highest expenditure groups, irrespective of region used intensively more transport fuel than the poorest households.

Table 3.

Shares of petroleum products expenditure in total household expenditure for quintile groups in urban and rural areas (percent).

\begin{tabular}{|c|c|c|c|c|c|c|}
\hline & \multirow{2}{*}{ All energy sources } & \multicolumn{5}{|c|}{ Petroleum products } \\
\hline & & All & Paraffin & Gas & Other domestic fuel & Transport fuel \\
\hline Urban & 8.4 & 4.1 & 0.3 & 0.1 & 0.0 & 3.7 \\
\hline Quintile 1 & 8.8 & 4.5 & 4.3 & 0.2 & 0.0 & 0.0 \\
\hline Quintile 2 & 8.0 & 2.8 & 2.6 & 0.1 & 0.0 & 0.1 \\
\hline Quintile 3 & 7.4 & 2.3 & 1.7 & 0.1 & 0.0 & 0.5 \\
\hline Quintile 4 & 7.6 & 2.3 & 0.7 & 0.1 & 0.0 & 1.5 \\
\hline Quintile 5 & 8.6 & 4.6 & 0.0 & 0.1 & 0.0 & 4.5 \\
\hline Rural & 9.1 & 4.4 & 1.5 & 0.3 & 0.3 & 2.3 \\
\hline Quintile 1 & 7.8 & 3.5 & 3.4 & 0.1 & 0.0 & 0.0 \\
\hline Quintile 2 & 7.8 & 3.4 & 3.1 & 0.2 & 0.0 & 0.1 \\
\hline Quintile 3 & 7.6 & 3.0 & 2.1 & 0.3 & 0.1 & 0.5 \\
\hline Quintile 4 & 7.8 & 3.7 & 1.3 & 0.6 & 0.1 & 1.7 \\
\hline Quintile 5 & 11.1 & 6.0 & 0.3 & 0.3 & 0.6 & 4.8 \\
\hline All & 8.5 & 4.2 & 0.5 & 0.1 & 0.1 & 3.5 \\
\hline
\end{tabular}

Source: author's calculation using the South African Income and Expenditure Survey for year 2000. 
The petroleum-products expenditure pattern described above is also similar to those of the "Black" and "Coloured" population groups (Table 4). ${ }^{15}$ However, poor "White" households and somewhat poor "Asian" households do not rely on paraffin as a primary source of liquid fuel and gas.

Table 4.

Shares of petroleum products expenditure in total household expenditure for quintile and racial population groups (percent).

\begin{tabular}{|l|l|l|l|l|l|l|l|}
\hline & \multirow{2}{*}{ All energy sources } & \multicolumn{5}{l|}{ Petroleum products } \\
\cline { 3 - 8 } & & All & Paraffin & Gas & Other domestic fuel & Transport fuel \\
\hline Black & $\mathbf{7 . 5}$ & $\mathbf{3 . 4}$ & $\mathbf{1 . 1}$ & $\mathbf{0 . 2}$ & $\mathbf{0 . 0}$ & $\mathbf{2 . 1}$ \\
\hline Quintile 1 & 8.2 & 4.0 & 3.9 & 0.1 & 0.0 & 0.0 \\
\hline Quintile 2 & 7.9 & 3.1 & 2.9 & 0.1 & 0.0 & 0.1 \\
\hline Quintile 3 & 7.2 & 2.6 & 2.0 & 0.2 & 0.0 & 0.4 \\
\hline Quintile 4 & 6.9 & 2.3 & 1.0 & 0.2 & 0.0 & 1.1 \\
\hline Quintile 5 & 7.9 & 4.5 & 0.2 & 0.1 & 0.1 & 4.1 \\
\hline Coloured & $\mathbf{8 . 8}$ & $\mathbf{3 . 5}$ & $\mathbf{0 . 2}$ & $\mathbf{0 . 1}$ & $\mathbf{0 . 1}$ & $\mathbf{3 . 1}$ \\
\hline Quintile 1 & 8.4 & 2.8 & 2.5 & 0.3 & 0.0 & 0.0 \\
\hline Quintile 2 & 8.1 & 2.1 & 1.6 & 0.3 & 0.0 & 0.2 \\
\hline Quintile 3 & 7.9 & 1.6 & 0.8 & 0.4 & 0.1 & 0.3 \\
\hline Quintile 4 & 7.9 & 1.8 & 0.2 & 0.2 & 0.0 & 1.4 \\
\hline Quintile 5 & 9.2 & 4.3 & 0.0 & 0.1 & 0.1 & 4.1 \\
\hline Asian & $\mathbf{1 0 . 5}$ & $\mathbf{4 . 7}$ & $\mathbf{0 . 0}$ & $\mathbf{0 . 1}$ & $\mathbf{0 . 0}$ & $\mathbf{4 . 6}$ \\
\hline Quintile 1 & 6.8 & 1.6 & 1.6 & 0.0 & 0.0 & 0.0 \\
\hline
\end{tabular}




\begin{tabular}{|l|l|l|l|l|l|l|l|}
\hline & \multirow{2}{*}{ All energy sources } & \multicolumn{5}{l|}{ Petroleum products } \\
\cline { 3 - 8 } & & All & Paraffin & Gas & Other domestic fuel & Transport fuel \\
\hline Quintile 2 & 5.2 & 0.8 & 0.0 & 0.1 & 0.0 & 0.7 \\
\hline Quintile 3 & 14.2 & 1.3 & 0.4 & 0.2 & 0.0 & 0.7 \\
\hline Quintile 4 & 12.5 & 3.2 & 0.0 & 0.1 & 0.0 & 3.1 \\
\hline Quintile 5 & 10.2 & 5.1 & 0.0 & 0.1 & 0.1 & 4.9 \\
\hline White & $\mathbf{9 . 1}$ & $\mathbf{4 . 9}$ & $\mathbf{0 . 0}$ & $\mathbf{0 . 1}$ & $\mathbf{0 . 1}$ & 4.7 \\
\hline Quintile 1 & 3.6 & 0.5 & 0.0 & 0.0 & 0.0 & 0.5 \\
\hline Quintile 2 & 6.7 & 1.4 & 0.1 & 0.1 & 0.0 & 1.2 \\
\hline Quintile 3 & 14.6 & 4.2 & 0.0 & 0.0 & 0.0 & 4.2 \\
\hline Quintile 4 & 13.1 & 5.1 & 0.0 & 0.1 & 0.1 & 4.9 \\
\hline Quintile 5 & 9.0 & 4.9 & 0.0 & 0.1 & 0.1 & 4.7 \\
\hline All & $\mathbf{8 . 5}$ & $\mathbf{4 . 2}$ & $\mathbf{0 . 5}$ & $\mathbf{0 . 1}$ & $\mathbf{0 . 1}$ & $\mathbf{3 . 5}$ \\
\hline
\end{tabular}

Source: author's calculation using the South African Income and Expenditure Survey for year 2000.

Transport service expenditure is an important component of the total household expenditure (Table 5). It represented an average of $4.5 \%$ of the total expenditure in South Africa for the year 2000. For South Africa as a whole, and in both urban and rural areas, and among the "Black" population group, median quintile groups allocate a greater share of their consumption expenditure to transport services. ${ }^{16}$ The share of transport expenditure increases with the total consumption expenditure for "Coloured" and "White" population groups while the opposite is observed for the "Asian" population group. 
Table 5.

Shares of transport expenditure in total household expenditure (percent).

\begin{tabular}{|c|c|c|c|c|c|c|c|}
\hline & \multirow{2}{*}{ All } & \multicolumn{2}{|l|}{ Areas } & \multicolumn{4}{|c|}{ Population group } \\
\hline & & Urban & Rural & Black & Coloured & Asian & White \\
\hline Quintile 1 & 4.2 & 4.9 & 3.4 & 4.3 & 2.2 & 6.1 & 0.3 \\
\hline Quintile 2 & 4.7 & 5.9 & 3.2 & 4.9 & 2.4 & 0.5 & 0.8 \\
\hline Quintile 3 & 5.8 & 6.6 & 4.0 & 6.2 & 2.8 & 3.6 & 1.5 \\
\hline Quintile 4 & 5.4 & 5.5 & 4.6 & 6.2 & 3.9 & 3.2 & 1.6 \\
\hline Quintile 5 & 4.3 & 4.4 & 2.7 & 4.5 & 3.9 & 2.2 & 4.4 \\
\hline All & 4.5 & 4.6 & 3.5 & 5.2 & 3.8 & 2.3 & 4.3 \\
\hline
\end{tabular}

Source: author's calculation using the South African Income and Expenditure Survey for year 2000.

After exploring the income and expenditure survey, we perform a simple exercise of doubling separately the price of major petroleum-products, i.e. paraffin and transport fuel and then measure its impacts on households' cost of living, that is, the consumption price index (price of the same bundle of commodities) and the equivalent variation in consumer welfare.

\subsubsection{Changes in consumer price index and equivalent welfare variation of doubling the prices of paraffin}

The expenditure pattern of paraffin (Table 3, Table 4 and Table 5) implies that the impact of the paraffin price rise would strongly be regressive, with the lowest quintile being much more impacted than the highest expenditure quintile. The impact of doubling the paraffin price on the cost of living presented in Table 6 shows that it is most burdensome for the poorest quintiles. Table 7 presents the equivalent welfare loss of the increase of the cost of living in terms of the equivalent variation of the expenditure. The percentage increase of total household consumption 
expenditure is most marked for the rural households and among the "Black" population group whose total household expenditures increase by $1.5 \%$ and $1.1 \%$ on average, respectively. However, the most affected household group remains the lowest expenditure quintile group in urban areas with an increase of $4.3 \%$ of their consumption expenditure and a welfare loss equivalent to $2.9 \%$ of the total consumption expenditure. Poor households in rural areas and among the "Black" population in particular witness an increase of their cost of living by $3.4 \%$ and $3.9 \%$, respectively. This is much higher than their corresponding highest expenditure quintile groups whose comparable cost of living increases are $0.3 \%$ and $0.2 \%$, respectively. This study does not consider the fact that these poor household, particularly the rural based households, may be able to substitute paraffin by other sources such as biomass. In such cases, welfare loss as measured in this paper may be somewhat reduced.

Table 6.

Estimated percentage changes in household expenditure.

\begin{tabular}{|c|c|c|c|c|c|c|c|}
\hline & \multirow{2}{*}{ All } & \multicolumn{2}{|l|}{ Areas } & \multicolumn{4}{|c|}{ Population group } \\
\hline & & Urban & Rural & Black & Coloured & Asian & White \\
\hline Quintile 1 & 3.8 & 4.3 & 3.4 & 3.9 & 2.5 & 1.6 & 0.0 \\
\hline Quintile 2 & 2.9 & 2.6 & 3.1 & 2.9 & 1.6 & 0.0 & 0.1 \\
\hline Quintile 3 & 1.9 & 1.7 & 2.1 & 2.0 & 0.8 & 0.4 & 0.0 \\
\hline Quintile 4 & 0.8 & 0.7 & 1.3 & 1.0 & 0.2 & 0.0 & 0.0 \\
\hline Quintile 5 & 0.0 & 0.0 & 0.3 & 0.2 & 0.0 & 0.0 & 0.0 \\
\hline All & 0.5 & 0.3 & 1.5 & 1.1 & 0.2 & $\mathbf{0 . 0}$ & 0.0 \\
\hline
\end{tabular}

Source: author's calculation using the South African Income and Expenditure Survey for year 2000 . 


\section{Table 7.}

Estimated percentage changes in welfare (equivalent variation).

\begin{tabular}{|c|c|c|c|c|c|c|c|}
\hline & \multirow{2}{*}{ All } & \multicolumn{2}{|l|}{ Areas } & \multicolumn{4}{|c|}{ Population group } \\
\hline & & Urban & Rural & Black & Coloured & Asian & White \\
\hline Quintile 1 & -2.5 & -2.9 & -2.3 & -2.6 & -1.7 & -1.1 & 0.0 \\
\hline Quintile 2 & -1.9 & -1.8 & -2.1 & -2.0 & -1.1 & 0.0 & -0.1 \\
\hline Quintile 3 & -1.3 & -1.2 & -1.4 & -1.4 & -0.5 & -0.3 & 0.0 \\
\hline Quintile 4 & -0.5 & -0.4 & -0.9 & -0.7 & -0.2 & 0.0 & 0.0 \\
\hline Quintile 5 & 0.0 & 0.0 & -0.2 & -0.1 & 0.0 & 0.0 & 0.0 \\
\hline All & -0.3 & -0.2 & -1.0 & -0.8 & -0.1 & 0.0 & 0.0 \\
\hline
\end{tabular}

Source: author's calculation using the South African Income and Expenditure Survey for year 2000.

\subsubsection{Changes in the consumer price index and equivalent welfare variation of doubling the prices of transport fuel}

The lessons learned from a 100\% price increase of transport fuel (petrol and diesel) are also clear (Table 8 and Table 9). The richer households would be hit much harder than poorer households for all of the household categories accounted for. As the poorest households certainly do not own their own vehicles and high transport fuel prices directly impact most on the richest households, one would expect that poor households are affected more through the rise of public transport cost. The next section discusses the distributional impacts of rising transport cost as a consequence of high oil and oil-products prices. 
Table 8 .

Estimated percentage changes in household expenditure.

\begin{tabular}{|c|c|c|c|c|c|c|c|}
\hline & \multirow{2}{*}{ All } & \multicolumn{2}{|l|}{ Areas } & \multicolumn{4}{|c|}{ Population group } \\
\hline & & Urban & Rural & Black & Colored & Asian & White \\
\hline Quintile 1 & 0.0 & 0.0 & 0.0 & 0.0 & 0.0 & 0.0 & 0.5 \\
\hline Quintile 2 & 0.1 & 0.1 & 0.1 & 0.1 & 0.2 & 0.7 & 1.2 \\
\hline Quintile 3 & 0.5 & 0.5 & 0.5 & 0.4 & 0.4 & 0.7 & 4.2 \\
\hline Quintile 4 & 1.6 & 1.5 & 1.8 & 1.2 & 1.4 & 3.1 & 5.0 \\
\hline Quintile 5 & 4.6 & 4.6 & 5.4 & 4.2 & 4.2 & 5.0 & 4.8 \\
\hline All & 3.6 & 3.8 & 2.6 & 2.2 & 3.2 & 4.7 & 4.8 \\
\hline
\end{tabular}

Source: author's calculation using the South African Income and Expenditure Survey for year 2000 .

Table 9.

Estimated percentage changes in welfare (equivalent variation).

\begin{tabular}{|l|l|l|l|l|l|l|l|}
\hline & \multirow{2}{*}{ All } & \multicolumn{2}{|l|}{ Areas } & \multicolumn{4}{l|}{ Population group } \\
\cline { 8 - 10 } & & Urban & Rural & Black & Colored & Asian & White \\
\hline Quintile 1 & 0.0 & 0.0 & 0.0 & 0.0 & 0.0 & 0.0 & -0.4 \\
\hline Quintile 2 & -0.1 & -0.1 & -0.1 & -0.1 & -0.1 & -0.5 & -0.8 \\
\hline Quintile 3 & -0.3 & -0.3 & -0.3 & -0.3 & -0.3 & -0.5 & -2.8 \\
\hline Quintile 4 & -1.0 & -1.0 & -1.2 & -0.8 & -0.9 & -2.0 & -3.3 \\
\hline
\end{tabular}




\begin{tabular}{|l|l|l|l|l|l|l|l|l|}
\hline & \multirow{2}{*}{ All } & \multicolumn{2}{|l|}{ Areas } & \multicolumn{4}{l|}{ Population group } \\
\cline { 4 - 6 } & & Urban & Rural & Black & Colored & Asian & White \\
\hline Quintile 5 & -3.1 & -3.0 & -3.5 & -2.7 & -2.8 & -3.3 & -3.2 \\
\hline All & $\mathbf{- 2 . 4}$ & $\mathbf{- 2 . 5}$ & $-\mathbf{- 1 . 7}$ & $\mathbf{- 1 . 4}$ & $\mathbf{- 2 . 1}$ & $\mathbf{- 3 . 1}$ & $\mathbf{- 3 . 2}$ \\
\hline
\end{tabular}

Source: author's calculation using the South African Income and Expenditure Survey for year 2000.

\subsubsection{Changes in consumer price index and equivalent welfare variation of a $15 \%$ increase of transport prices}

The $15 \%$ increase of transport cost is the same one that has been calculated for a doubling of transport fuel prices. The size of the increase is less than that of the previous simulations.

Allowing for no inter-commodity substitution, the distributional impacts of the estimated price increases of transport show no significant differences among household categories (Table 10 and Table 11). The results of the experiment are in line with the analysis of the shares of transport expenditure in total household expenditure. Median quintile expenditure groups observe the highest impact both in urban and rural areas, and among the "Black" population. The impact is progressive among the "Coloured" and "White" population group, while it is regressive among the "Asian" population group.

Table 10.

Estimated percentage changes in household expenditure.

\begin{tabular}{|l|l|l|l|l|l|l|l|l|}
\hline & \multirow{2}{*}{ All } & \multicolumn{2}{l|}{ Areas } & \multicolumn{3}{l|}{ Population group } \\
& & Urban & Rural & Black & Colored & Asian & White \\
\hline Quintile 1 & 0.56 & 0.66 & 0.48 & 0.57 & 0.27 & 0.84 & 0.05 \\
\hline
\end{tabular}




\begin{tabular}{|c|c|c|c|c|c|c|c|}
\hline & \multirow{2}{*}{ All } & \multicolumn{2}{|l|}{ Areas } & \multicolumn{4}{|c|}{ Population group } \\
\hline & & Urban & Rural & Black & Colored & Asian & White \\
\hline Quintile 2 & 0.64 & 0.80 & 0.48 & 0.66 & 0.30 & 0.10 & 0.18 \\
\hline Quintile 3 & 0.80 & 0.91 & 0.59 & 0.84 & 0.40 & 0.64 & 0.26 \\
\hline Quintile 4 & 0.78 & 0.80 & 0.70 & 0.89 & 0.56 & 0.53 & 0.24 \\
\hline Quintile 5 & 0.58 & 0.60 & 0.36 & 0.69 & 0.55 & 0.34 & 0.56 \\
\hline All & 0.62 & 0.65 & 0.50 & 0.76 & 0.53 & 0.37 & 0.55 \\
\hline
\end{tabular}

Source: author's calculation using the South African Income and Expenditure Survey for year 2000 .

Table 11.

Estimated percentage changes in welfare (equivalent variation).

\begin{tabular}{|l|l|l|l|l|l|l|l|}
\hline & All & \multicolumn{2}{|l|}{ Areas } & \multicolumn{3}{l|}{ Population group } \\
\cline { 7 - 9 } \cline { 6 - 8 } & & Urban & Rural & Black & Colored & Asian & White \\
\hline Quintile 1 & -0.52 & -0.61 & -0.45 & -0.53 & -0.25 & -0.77 & -0.05 \\
\hline Quintile 2 & -0.59 & -0.74 & -0.45 & -0.61 & -0.28 & -0.09 & -0.17 \\
\hline Quintile 3 & -0.74 & -0.84 & -0.54 & -0.78 & -0.37 & -0.59 & -0.24 \\
\hline Quintile 4 & -0.72 & -0.74 & -0.65 & -0.82 & -0.52 & -0.49 & -0.22 \\
\hline Quintile 5 & -0.53 & -0.55 & -0.33 & -0.64 & -0.50 & -0.32 & -0.51 \\
\hline All & -0.58 & -0.60 & -0.46 & -0.70 & -0.49 & -0.34 & -0.50 \\
\hline
\end{tabular}

Source: author's calculation using the South African Income and Expenditure Survey for year 2000. 
A number of other studies have assessed the impact of large energy price increases using household expenditure surveys and/or an input-output table. The UNDP/ESMAP (2005) reviews studies which estimate both direct effects of price increases (through the share of petroleumproducts prices in the budget) and indirect prices increases of goods whose prices have been affected by the shock. It appears that large increases of prices of petroleum-products (kerosene, LPG, gasoline, diesel, and fuel oil) and other products (transport and energy) result in a welfare loss of all household groups. This is most marked for the rural households and the poorest income groups. These results are estimates for cash expenditures and do not account for non cash use of biomass which might reduce the proportionate welfare loss to some extent.

\section{Conclusion}

Using an input-output model combined with a household survey for South Africa, we quantify the economic impacts of a sustained oil price increase above US\$55 a barrel. Under the assumption of zero elasticity for oil and oil products demand, we found that a price increase will likely lead to an equivalent increase of the oil import bill as the quantities imported do not change. The oil import bill increases to $10.1 \%$ of the total import bill and this represents a significant shift in the import structure and the trade figures of the country. Imports become more expensive and exports less valuable and consequently real national income drops. Lower national income reduces demand for imported and domestic commodities and investment, leading to a drop of GDP.

Assuming zero price elasticity of demand for petroleum-products in the short term, any modification in petroleum-products prices will be translated into an increase in the input cost through the oil-input bill. Transport services and primary plastics are the most affected industries. All of the industries falling into the high intensive oil-use group witness an increase of their input cost above the economy-wide average. When we assume a low possibility for quantity adjustments in the short term instead, most of the products/industries experiencing an increase in their cost fall into the group of high intensive oil using industries. The incidence is significant on the cost of "transport services" and "primary plastics". The impacts of higher-oil prices on the transport and primary plastics industries accounts for the largest share of the effects in other 
industries. They play a key role in the distributional impacts of high oil prices among industries and households.

Analysis of the income and expenditure survey shows that the lowest expenditure groups rely primarily on paraffin as a source of liquid fuel and gas. In contrast, the highest expenditure groups used intensively more transport fuel than the poorest households. The pattern of expenditure among rural and urban household groups is somewhat similar to the entire South African figures with a minor difference that rural households rely more on paraffin compared to urban households. This petroleum-products expenditure pattern is also similar to those of the "Black" and "Coloured" population groups. The impact of doubling the paraffin price on the cost of living shows that it is most burdensome for the poorest quintiles. The percentage increase of total household consumption expenditure on fuel is most marked for the rural households and among the "Black" population group. Poor households in rural areas and among the "Black" population in particular witness an increase of their cost of living which is much higher than their corresponding highest expenditure quintile groups. An increase of transport fuel (petrol and diesel) on the other hand hits the richer households much harder than poorer households for all of the household categories accounted for. The distributional impacts of rising transport cost as a consequence of high oil and oil-products prices shows that median quintile expenditure groups observe the highest impact both in urban and rural areas.

\section{Acknowledgements}

We gratefully acknowledge the financial contribution of the Financial and Fiscal Commission (Ismael Fofana and Ramos Mabugu participation). We are grateful for comments from participants at seminars held at the Financial and Fiscal Commission (Midrand, South Africa) and the University of Pretoria (Economics Department). We are also grateful to Bernard Decaluwé and John Cockburn from Laval University in Canada who were instrumental in the development of models and data approaches used in this paper. The views expressed in this paper are those of the author(s) and do not necessarily represent those of the institutions that they are involved with. 


\section{References}

Bussolo, M., Chemingui, M., O'Connor, D., 2003. A Multi-Region Social Accounting Matrix (1995) and Regional Environmental General Equilibrium Model for India (REGEMI). OECD Development Centre Working Papers 213, OECD Development Centre.

Capros, P., Georgakopoulos, T., Filippoupolitis, A., Kotsomiti, S., Atsaves, G., 1997. The GEME3 model: Reference manual. National Technical University of Athens, ( http://geme3.zew.de/geme3ref.pdf)

Stan du Plessis, Ben Smit, 2006. Economic growth in South Africa since 1994. Working Papers 01/2006, Stellenbosch University, Department of Economics.

Essama-Nssah, B., Go, D., Kearney, M., Korman, V., Robinson, S., Thierfelder, K., 2007.

Economywide and Distributional Impacts of an Oil Price Shock on the South African Economy, Policy Research Working Paper 4354, Washington DC, The World Bank.

Faruqee, H., Isard, P., Laxton, D., Prasad, E., Turtelboom, B., 1998. Multimod Mark III: The Core Dynamic and Steady State Model, IMF Occasional Papers 164, International Monetary Fund.

International Energy Agency, 2009. World Energy Outlook. Available at (http://www.iea.org/weo/model.asp)

International Monetary Fund (IMF), 2000. The Impact of Higher Oil Prices on the Global Economy. Available at: (http://www.imf.org/external/pubs/ft/oil/2000/oilrep.PDF).

McDonald, S., van Schoor, M.A., 2005. Computable General Equilibrium (CGE) Analysis of the Impact of an Oil Price Increase in South Africa, PROVIDE Project Working Paper, 1.

Richardson, P., 1988. The structure and simulation properties of OECD's INTERLINK model, OECD Economic Studies, No. 10, Spring.

S. Robinson, A. Cattaneo and M. El-Said, Updating and estimating a social accounting matrix using cross entropy methods, economic systems research, Taylor and Francis Journals 13 (1) (2001), pp. 47-64 March.

B. Smit, S. van der Berg, D. Krueger, I. Adams, L. Ellis, T. Gutuza, L. Lootz, K. Mbangeleli, C. Murray, W. Pienaar, L. Ramuhulu, K. Saller, A. Scholtz and M. Sheraton, The Feasibility of a Fuel Tax Levy in the Western Cape, Bureau for Economic Research, Stellenbosch, Cape Town, South Africa (2003). 
South African Reserve Bank (SARB) database, various years, (www.reservebank.co.za).

South Africa. Info, 2007. South Africa's population. Available at

(http://www.southafrica.info/about/people/population.htm).

Statistics South Africa, 2003. Final Supply and Use Tables, 2000: an input-output framework, Pretoria, South Africa.

Statistics South Africa, 2002. Income and Expenditure Survey, 2000. Statistical release P0111.

Pretoria: Statistics South Africa.

United Nations Development Program/World Bank Energy Sector Management Assistance

Programme, 2005.The Impact of Higher Oil Prices on Low Income Countries and on the Poor.

World Bank, Washington DC.

J. van Heerden, R. Gerlagh, J. Blignaut, S. Hess, R. Mabugu and M. Mabugu, Searching for triple dividends in South Africa: fighting $\mathrm{CO}_{2}$ pollution and poverty while promoting growth, Energy Journal 27 (2006), pp. 113-142.

${ }^{1}$ Note, however, South Africa has a huge synthetic fuel industry that accounts for between 35\% and $40 \%$ of domestic liquid petroleum sales.

${ }^{2}$ van Heerden et al. (2006) have studied the effects of environmental taxation under different assumptions about revenue recycling. They manage to identify triple dividends.

${ }^{3}$ General equilibrium model for studying economy-energy-environment interactions for Europe and the World built under the auspices of European Commission (DG-Research) (see Capros et al., 1997).

${ }^{4}$ Regional Environmental General Equilibrium Model for India by Bussolo et al. (2003).

${ }^{5}$ This is the approach used in this paper which is simpler than the CGE approaches mentioned earlier.

${ }^{6}$ General equilibrium analysis is a useful tool for measuring the direct and indirect effects of shocks wherever they occur, in or outside the economy.

${ }^{7}$ A cross entropy method (Robinson et al., 2001) is used to rebalance the sampling weight subject to limited constraints, among others, the shares of population groups, and the poverty and inequality indices.

${ }^{8}$ A $100 \%$ increase of the average price of imported crude oil corresponds roughly to an additional US \$20 to its average price in year 2000 . 
${ }^{9}$ The assumption means the demand for oil and oil products is insensitive to the changes in prices (own and cross). Therefore, one should interpret the results of the analysis as the worst case for the increase of oil and oil products price in South Africa.

${ }^{10}$ In December 2007, one United States Dollar was equivalent to R6.80.

11 These are consumption costs of oil and oil products as seen in Eq. (2).

12 The GDP reduction is estimated to be $0.7 \%$ with a $100 \%$ increase of crude oil prices combined with unchanged petroleum-products prices.

${ }^{13}$ Final Supply and Use Tables, 2000: an input-output framework/Statistics South Africa; Statistics South Africa (2003). At the time of analysis, this was the latest supply and use table available. Thus, the picture may change as new data becomes available.

14 The 2000 IES codes are used in defining the urban and rural household categories.

${ }^{15}$ Definition of households by colour is one of the popular ways used in South Africa. Including the race based definition is rooted in the apartheid period policies. "Black" people of South Africa are the natives of the country and these mainly include the Zulu, Xhosa, Ndebele, Swazi, Sotho-Tswana, Tsonga; and the Venda. 'White' people are mainly descendents of the colonial immigrants of Dutch, German, French Huguenot and British origins. 'Coloureds' are people of a mixed race and 'Asians' are mainly people of India descend, (South Africa. Info, 2007).

${ }^{16}$ It is important to note that many of the victims of Apartheid were forced to (and often still do) live outside of commercial centres. This implies a heavy travel burden to and from work-much more so than in many "normal" developing countries. 